\title{
Diurnal changes in hypothalamic neuropeptide and SOCS-3 expression: effects of lactation and relationship with serum leptin and food intake
}

\author{
R G P Denis ${ }^{1,2}$, C Bing ${ }^{1}$, S Brocklehurst ${ }^{3}$, J A Harrold ${ }^{1}$, \\ R G Vernon ${ }^{2}$ and G Williams ${ }^{1}$ \\ ${ }^{1}$ Diabetes and Endocrinology Research Group, Department of Medicine, The University of Liverpool, Liverpool L69 3GA, UK \\ ${ }^{2}$ Hannah Research Institute, Mauchline Road, Ayr KA6 5HL, UK \\ ${ }^{3}$ Biomathematics \& Statistics Scotland, Hannah Research Institute, Mauchline Road, Ayr KA6 5HL, UK. \\ (Requests for offprints should be addressed to R Vernon; Email:vernonr@hri.sari.ac.uk)
}

\begin{abstract}
Rats normally eat about $85 \%$ of their food at night. Lactation increases food intake 3- to 4-fold, but the diurnal pattern of food intake persists. The mechanisms responsible for the diurnal and lactation-induced changes in food intake are still unresolved, hence we have further investigated the possible roles of serum leptin and hypothalamic expression of neuropeptide Y (NPY), agouti-related peptide (AgRP) and pro-opiomelanocortin (POMC) in rats. Suppressor of cytokine signalling-3 (SOCS-3) acts as a feedback inhibitor of leptin signalling in the hypothalamus, hence changes in expression of SOCS-3 were also investigated.

Changes in expression of NPY, AgRP or POMC alone could not account for the diurnal changes in intake and their alteration by lactation. However, there were increased AgRP mRNA:POMC mRNA ratios at night and also during lactation, which were very similar to
\end{abstract}

estimated changes in food intake. Such changes in expression may result in dominance of the orexigenic AgRP peptide over the appetite-suppressing POMC-derived peptides, and so could contribute to the hyperphagia in these states. Diurnal and lactation-related changes in the AgRP mRNA:POMC mRNA ratio and food intake are not due to changes in leptin alone. However, hypoleptinaemia, possibly through increased expression of NPY, may contribute to the hyperphagia of lactation.

In the dark, expression of SOCS-3 was decreased in non-lactating rats; lactation decreased SOCS-3 expression in both light and dark phases. However, such changes are likely to enhance the ability of leptin-responsive neurones to transmit the leptin signal, and so are unlikely to contribute to either the nocturnal increase in appetite or the hyperphagia of lactation.

Journal of Endocrinology (2004) 183, 173-181

\section{Introduction}

Rats are primarily nocturnal and eat about $85 \%$ of their food at night (Kimura et al. 1970, Bruckdorfer et al. 1974). Lactation increases food intake 3- to 4-fold in rats, reflecting the considerable nutritional demands of the mammary gland (Wade \& Schneider 1992, Barber et al. 1997), but the diurnal pattern of food intake persists, with about $65 \%$ of food still being consumed at night (Strubbe \& Gorissen 1980, Munday \& Williamson 1983, Pickavance et al. 1996, Denis et al. 2003a). Despite the hyperphagia, lactating rats enter and remain in a state of overall net negative energy balance (Barber et al. 1997). The mechanisms regulating both the diurnal changes in food intake and the hyperphagia of lactation are not resolved.

Central control of appetite involves numerous neural circuits, including the hypothalamic neurones expressing neuropeptide Y (NPY) and agouti-related peptide (AgRP), and others that produce pro-opiomelanocortin (POMC), the precursor of $\alpha$-melanocyte-stimulating hormone ( $\alpha$-MSH; Elmquist et al. 1999, Schwartz et al. 2000, Williams et al. 2001, Pritchard et al. 2002). NPY and AgRP stimulate, while $\alpha-\mathrm{MSH}$ inhibits feeding. $\alpha-\mathrm{MSH}$ activates the melanocortin-4 receptor (MC4-R), which is antagonised by AgRP (Elmquist et al. 1999, Schwartz et al. 2000, Williams et al. 2001).

Leptin, a peptide hormone secreted predominantly by adipocytes, acts on the hypothalamus to restrain appetite and increase energy expenditure (Friedman \& Halaas 1998, Ahima \& Flier 2000, Ahima et al. 2000, Elmquist 2001). These central actions are partly explained by leptin's ability to inhibit the NPY/AgRP neurones while stimulating the POMC neurones (Ahima \& Flier 2000, Ahima et al. 2000, Schwartz et al. 2000, Elmquist 2001, 
Williams et al. 2001). During periods of negative energy balance, serum leptin concentrations fall, leading to increased expression of NPY and AgRP, and decreased expression of POMC in the hypothalamus; these changes are probably important in increasing hunger and decreasing energy expenditure in conditions such as fasting and diabetes (Friedman \& Halaas 1998, Ahima 2000, Ahima \& Flier 2000, Ahima et al. 2000, Williams et al. 2001).

Leptin apparently modulates its own effects within the hypothalamus, as it inhibits the expression of the ' $b$ ' isoform of the leptin receptor $(\mathrm{Ob}-\mathrm{Rb})$ and induces downregulation of the receptor protein (Mercer et al. 1997, Baskin et al. 1998, Uotani et al. 1999). Leptin also induces expression of suppressor of cytokine signalling-3 (SOCS3), a protein that inhibits a critical intracellular signalling pathway activated by leptin (Björbaek et al. 1999).

The mechanisms driving the diurnal pattern of feeding in rats are unexplained. Serum leptin concentrations are increased at night (Pickavance et al. 1998, Xu et al. 1999, Ahren 2000, Pu et al. 2000, Kalsbeek et al. 2001). Thus, the diurnal pattern of feeding in rats is not due to changes in serum leptin concentration; rather, the nocturnal rise in serum leptin is at least partly due to the increase in food intake (Ahima et al. 1998, Xu et al. 1999). Hypothalamic NPY expression is decreased at night in male rats (Xu et al. 1999), which is consistent with the nocturnal rise in serum leptin, but not with increased food intake. By contrast, AgRP expression increases at night in male rats ( $\mathrm{Lu}$ et al. 2002); this could contribute to nocturnal hyperphagia, but appears inconsistent with the hyperleptinaemia. Reports of diurnal changes in POMC expression are inconsistent (Wise et al. 1990, Steiner et. al. 1994, Xu et al. 1999, Lu et. al. 2002).

The nocturnal increase in serum leptin is markedly attenuated and daytime leptin concentration appears generally decreased during lactation (Johnstone \& Higuchi 2001, Smith \& Grove 2002, Vernon et al. 2002); this hypoleptinaemia is thought to facilitate the hyperphagia of lactation. Consistent with the general decrease in serum leptin, hypothalamic expression of NPY and AgRP are increased during the daytime in lactating rats, while POMC is decreased (Smith \& Grove 2002, Vernon et al. 2002). The effects of lactation on the expression of these hypothalamic neuropetides at night is not known.

Here, we investigated further the mechanisms responsible for the diurnal pattern of food intake in rats - and its modulation by lactation - by determining diurnal changes in hypothalamic neuropeptide and SOCS-3 expression, their relationships to serum leptin and their modification by lactation. Changes in SOCS-3 expression do not explain the nocturnal or lactation-induced hyperphagia. However, we suggest that changes in the ratio of AgRP:POMC expression, and hence signalling through the MC4-R system, are important both for the diurnal rhythm of food intake and for the hyperphagia of lactation. Furthermore, neither changes in the
AgRP:POMC expression ratio nor food intake can be attributed to changes in leptin alone.

\section{Materials and Methods}

\section{Animals}

Female Wistar rats, raised at the Hannah Research Institute from stock obtained originally from A. Tuck and Sons, Ltd (Rayleigh, Essex, UK), were fed standard pelleted chow ad libitum (CRM diet, Labsure, Poole, Dorset, UK) and had free access to water. They were divided into two groups of 16 animals: one was maintained on a light-darkness schedule with lights on from $0700 \mathrm{~h}$ to $1900 \mathrm{~h}$ and the other with lights on from $2200 \mathrm{~h}$ to $1000 \mathrm{~h}$. Eight rats from each group were mated at about 10 weeks of age, while the others were kept for non-lactating controls. Litter size was adjusted to 10 pups within $24 \mathrm{~h}$ of birth. All animal procedures were approved by the Ethical Review Committee of the Hannah Research Institute.

After at least 4 weeks exposure to the specific lightdarkness regimen, non-lactating and lactating rats (day 14 of lactation) were killed $2 \mathrm{~h}$ into the light or dark phase. Trunk blood was collected and allowed to clot, and serum stored at $-20{ }^{\circ} \mathrm{C}$ for later analyses. The brain was frozen in liquid nitrogen and the hypothalamus dissected out en bloc under a binocular microscope, using consistent landmarks (Williams et al. 1988). The hypothalamic block was removed from a frontal slice of brain tissue between the optic chiasm and the mammillary bodies, using cuts made immediately below the anterior commissure and through the perihypothalamic sulci. The block was kept frozen in liquid nitrogen until mRNA extraction.

\section{Serum leptin}

Serum leptin concentration was determined by RIA using a commercial kit (Linco Research, Inc. MO, USA; distributed by Biogenesis, Poole, Dorset, UK).

\section{Quantitative reverse transcription $(R T)-P C R$}

RT-PCR was used to measure NPY, AgRP, POMC and SOCS-3 mRNAs. Total RNA was extracted from frozen dissected hypothalami, using Tri Reagent (Sigma). The yield and quality of extracted RNA were assessed by the 260:280 nm optical density ratio and electrophoresis, under denaturing conditions, on $1.1 \%$ agarose gel. Only samples displaying satisfactory quality were used for analysis. Total RNA was subjected to treatment with RNase-free DNase I (Roche) for $10 \mathrm{~min}$ at $37^{\circ} \mathrm{C}$ and a further $10 \mathrm{~min}$ at $75^{\circ} \mathrm{C}$.

Reverse transcription was carried out using optimized amounts $(1 \mu \mathrm{g})$ of total RNA with a Reverse-iT 1st Strand synthesis kit (Abgene, Epsom, Surrey, UK) in a final 
volume of $25 \mu$. First-strand cDNA species were PCR amplified using the following primers, obtained from Sigma-Genosys Ltd (Pampisford, UK) (sequence alignments were performed with the BLAST system): NPY, 5'-C GCCATGATGCTAGGTAAC-3' and 5'-CAGA CTGGTTTCACAGGATG-3' for a 379 bp sequence (Rybkin et al. 1997, accession number M20373); AgRP, 5'-AGAGTTCTCAGGTCTAAGTCT-3' and $5^{\prime}$-CTT GAAGAAGCGG CAGTAGCAC-3' corresponding to a 321 bp sequence (Korner et al. 2000, AF206017); POMC, 5'-AGCCTCTGTCCAGTCCTGAG-3' and 5'-CTTA GTCACTGCTCCTTAAC-3' corresponding to a 349 bp sequence (Drouin et al. 1985, K01877); SOCS-3, 5'-AC CAGCGCCACTTCTTCACA-3' and 5'-GTGGAG CATCATACTGGTCC-3' corresponding to a $450 \mathrm{bp}$ sequence (Björbaek et al. 2001, AJ249240). Complementary DNA was also generated for the housekeeping gene hypoxanthine-guanine phospho-ribosyltransferase (HPRT; Siegling et al. 1994, X62085) using 5'-CAG TCCCAGCGTCGTGATTA-3' and 5'-AGCAAGTC TTTCAGTCCTGTC-3' corresponding to a $138 \mathrm{bp}$ sequence.

For amplification of cDNA, PCR was performed with $1 \mu \mathrm{l}$ template cDNA and $35 \mu \mathrm{l}$ PCR mix $(1 \cdot 1 \times$ ReddyMix PCR master mix, $1.5 \mathrm{mM} \mathrm{MgCl}_{2}$; ABgene) on a thermal cycler (Hybaid, Ashford, UK). After initial denaturation at $94{ }^{\circ} \mathrm{C}$ for $5 \mathrm{~min}$, the samples were subjected to cycles of amplification: denaturation at $94{ }^{\circ} \mathrm{C}$ for $30 \mathrm{~s}$; annealing for $30 \mathrm{~s}$ at $58^{\circ} \mathrm{C}$ for AgRP, POMC and SOCS -3 , and $56^{\circ} \mathrm{C}$ for HPRT and NPY; and extension for $40 \mathrm{~s}$ at $72{ }^{\circ} \mathrm{C}$. Preliminary PCR experiments showed that the rate of amplification was linear for a limited number of cycles (data not shown), so the samples were subjected to 29 cycles of amplification for HPRT, 32 cycles for NPY and AgRP, and 38 cycles for SOCS-3 and POMC. As competition was observed between HPRT and other primers, each cDNA was amplified in individual tubes. After final extension at $72{ }^{\circ} \mathrm{C}$ for $7 \mathrm{~min}, 15 \mu \mathrm{l}$ of each mixture was subjected to electrophoresis on a $1 \cdot 1 \%$ agarose gel. Controls without reverse transcriptase were systematically performed to detect cDNA contamination. Bands were visualized and quantified using a digital image analysis system (Kodak 1-D, Kodak Eastman). Optical density was calculated for each gene product and the results expressed as the ratio of its density to that of the HPRT product.

\section{Statistical analyses}

Results were analysed by ANOVA, with physiological state, light/dark phase and their interactions as factors. For significant state-by-phase interactions, Tukey's post-hoc test was used to test the difference between means. Multiple regression analysis was used to investigate possible linear relationships of neuropeptide and SOCS-3 expression to serum leptin, and of POMC to SOCS-3 expression, together with the effect of physiological state and light/dark phase on these relationships. The fitted lines shown in Figs 2 and 3 correspond to the best-fitting regression models according to tests of significance. A $P$ value of 0.05 or less was considered as significant. All analyses were performed using Genstat (Genstat, 6th edition, Lawes Agricultural trust, VSN International Ltd, Oxford, UK), except for Tukey's test for which Minitab (Minitab 13, Minitab Inc., State College, PA, USA) was used.

\section{Results}

Food intake and serum leptin concentration

Daily food intake and serum leptin results from this experiment have already been described (Denis et al. 2003b). In brief, daily food intake was $14.3 \pm 1.7$ and $58 \cdot 2 \pm 3 \cdot 8 \mathrm{~g} / \mathrm{rat}$ for non-lactating and lactating rats respectively $(P<0 \cdot 001)$. Serum leptin concentrations were 1.81 and $3.79 \mathrm{ng} / \mathrm{ml}$ for non-lactating rats in the light and dark respectively, and 1.55 and $2.53 \mathrm{ng} / \mathrm{ml}$ for lactating rats in the light and dark phases respectively; all values are means of eight observations, and the common S.E.M. from ANOVA was $0 \cdot 22$. The nocturnal increase in leptin was significant in both states $(P<0.001$ for non-lactating and $P=0.017$ for lactating rats), and was significantly diminished $(P=0.026)$ by lactation. Lactation had no significant effect on serum leptin concentration during the light phase.

\section{Expression of hypothalamic genes}

NPY mRNA levels were significantly increased by lactation $(P<0 \cdot 001)$, but did not vary significantly with light/ dark phase $(P=0.073)$ (Fig. 1A). Lactation increased $(P=0.008)$ AgRP expression during the dark phase, but not in the light (Fig. 1B). There was no effect of light/dark phase on AgRP expression in either state (Fig. 1B). In non-lactating rats POMC expression was lower $(P=0 \cdot 002)$ in the dark phase than in the light (Fig. 1C). Lactation decreased expression of POMC in the light $(P=0.002)$, but did not decrease expression further in the dark (Fig. 1C). SOCS-3 expression was lower at night in both non-lactating and lactating rats $(P=0 \cdot 002)$ and was decreased during lactation in both light and dark phases $(P=0 \cdot 019)$ (Fig. 1D). The ratio of AgRP:POMC expression was higher at night in both physiological states $(P=0 \cdot 001)$ and was increased by lactation $(P=0.002)$ in both light and dark phases (Fig. 1E).

\section{Relationships between hypothalamic gene expression and serum} leptin concentration

There were significant, negative relationships between NPY $(P=0 \cdot 037$, Fig. $2 A)$, POMC $(P=0 \cdot 007$, Fig. $2 \mathrm{~B})$ 

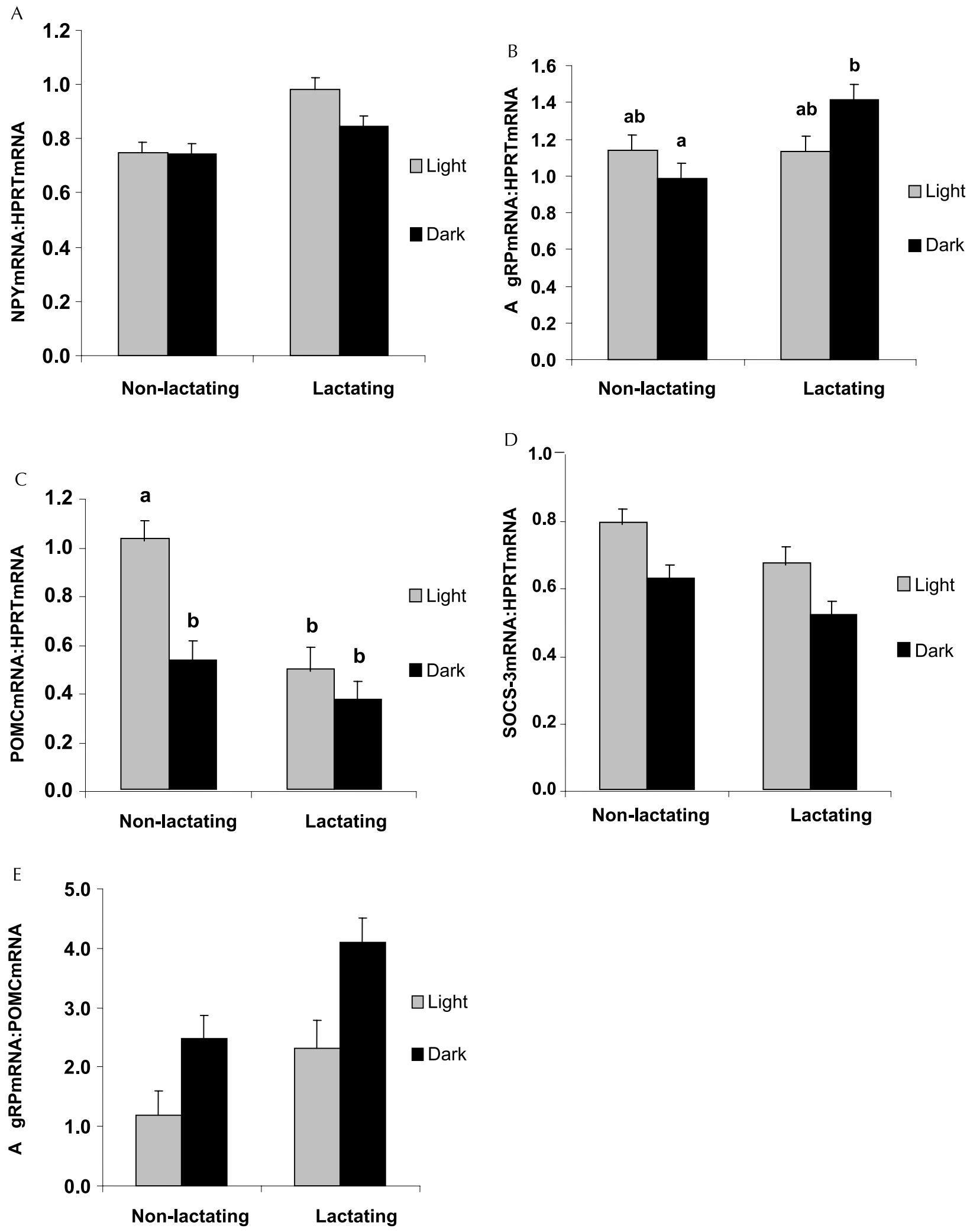
and SOCS-3 $(P=0.004$, Fig. 2C) and serum leptin. However, in each case the intercept with the $y$-axis, but not the gradient, was altered by state; for NPY, the intercept was also affected by light/dark phase (Fig. 2). For both POMC and SOCS-3 there was a significant effect of state $(P<0.001$ and $P=0.002$ respectively), such that for a given leptin concentration, less POMC and SOCS-3 was expressed during lactation (Fig. 2B and C). By contrast, for NPY the effect of lactation was different in the light and dark $(P=0.02$, Fig. $2 \mathrm{~A})$; in the light, less NPY was expressed for a given leptin concentration in non-lactating rats than during lactation $(P<0 \cdot 001$, Fig. $2 \mathrm{~A})$, whereas there was no effect of lactation in the dark phase. No significant relationships were found between serum leptin concentration and either hypothalamic AgRP expression or AgRP:POMC ratio $(P=0.622$ and $P=0.806$ respectively) (results not shown).

There was a highly significant positive relationship between POMC and SOCS-3 expression $(P<0 \cdot 001)$ (Fig. $3)$. The gradient did not change significantly with state or light/dark phase, but the $y$-intercept varied, such that there was more POMC for a given amount of SOCS-3 in non-lactating rats in the light phase than in the other three situations $(P \leq 0 \cdot 011$, Fig. 3).

\section{Discussion}

Diurnal changes in hypothalamic gene expression: relationship to leptin and food intake

The mechanisms regulating the diurnal changes in food intake in rats are poorly understood. Serum leptin, which is usually anorexic, is increased at night (Pickavance et al. 1998, Xu et al. 1999, Ahren 2000, Mastronardi et al. 2000, Nishiyama et al. 2000, Pu et al. 2000, Ziotopoulou et al. 2000, Kalsbeek et al. 2001, Denis et al. 2003a), probably due to the increase in food intake around the onset of night (Ahima et al. 1998, Xu et al. 1999). Whether the elevated leptin levels act to constrain nocturnal eating (that is, rats would eat even more if leptin concentration did not increase) or whether the hypothalamus becomes refractory to leptin at night is not known.

In male rats, increased AgRP expression at night suggests that it could promote nocturnal eating ( $\mathrm{Lu}$ et al. 2002), whereas a decrease in NPY expression at night (Xu et al. 1999) argues against involvement of NPY. In contrast to these studies with male rats, we found no diurnal change in either NPY or AgRP expression in the hypothalamus in non-lactating female rats. Our finding that POMC expression is decreased in the early hours of the dark period in non-lactating, female rats agrees with the results of Wise et al. (1990). Published diurnal changes in hypothalamic POMC expression in male rats are not consistent, but two reports suggest that expression may decrease at the onset of the dark period (Steiner et al. 1994, Xu et al. 1999), although no change was found by Lu et al. (2002). A decrease in hypothalamic POMC expression around the beginning of the dark period may thus contribute to the nocturnal hyperphagia in both sexes.

There was a negative correlation between NPY expression and serum leptin, which is consistent with known effects of leptin on hypothalamic NPY expression (Ahima \& Flier 2000, Ahima et al. 2000, Schwartz et al. 2000, Elmquist 2001, Williams et al. 2001). By contrast, there was no apparent relationship between serum leptin and AgRP expression, while a seemingly paradoxical, negative relationship between serum leptin and hypothalamic POMC expression was apparent. The latter, however, is probably due to the decrease in POMC expression in the dark, at a time when serum leptin is increased. Whether this rise in leptin subsequently causes an increase in POMC expression further into the dark period is unclear. Leptin infusion decreased NPY expression, but had no effect on POMC expression in fed rats (Ahima et al. 1999) and mice (Takahashi et al. 2002), implying a differential sensitivity to leptin of their respective neurones. Refractoriness of POMC neurones to leptin in the fed rat could explain why food intake is increased throughout the night despite continuing high levels of leptin (Xu et al. 1999, Ahren 2000, Mastronardi et al. 2000, Ziotopoulou et al. 2000, Kalsbeek et al. 2001, Nishiyama et al. 2001, Denis et al. 2003a).

Leptin increases hypothalamic expression of SOCS-3, and this then acts as a feedback inhibitor of leptin signalling (Björbaek et al. 1999). SOCS-3 expression is also regulated by other hormones and cytokines (Björbaek et al. 1999, Auernhammer \& Melmed 2001), hence we hypothesised that an increase in SOCS-3 at night could act to limit the response to leptin and so contribute to the hyperphagia. However, contrary to this idea, SOCS-3 expression fell during the dark despite the hyperleptinaemia. SOCS-3 is expressed in both POMC and NPY neurones (Elias et al. 1999, Baskin et al. 2000), but we suggest that the diurnal, and also lactation-induced,

Figure 1 Amount of NPY mRNA (A), AgRP mRNA (B), POMC mRNA (C) and SOCS-3 mRNA (D) relative to HRPT mRNA, and the ratio of AgRP:POMC mRNA (E) in the hypothalamus of non-lactating and lactating rats in the light and dark phases. Values are means \pm S.E.M., obtained by ANOVA, of eight observations for non-lactating rats, and six and eight observations for lactating rats, in the light and dark phases respectively. For NPY there was a significant effect of physiological state $(P<0 \cdot 001)$ but not light/dark phase $(P=0 \cdot 073)$. For SOCS-3 and AgRP:POMC ratio there was a significant effect of physiological state $(P=0 \cdot 019$ and $P=0.001$ respectively) and light/dark phase $(P=0.002$ and $P=0.001$ respectively). For AgRP and POMC there were significant physiological state by light/dark phase interactions $(P=0.017$ and $P=0.035$ respectively); for these variables, values (bars) without the same label (a or b) differ significantly $(P<0 \cdot 05)$. 

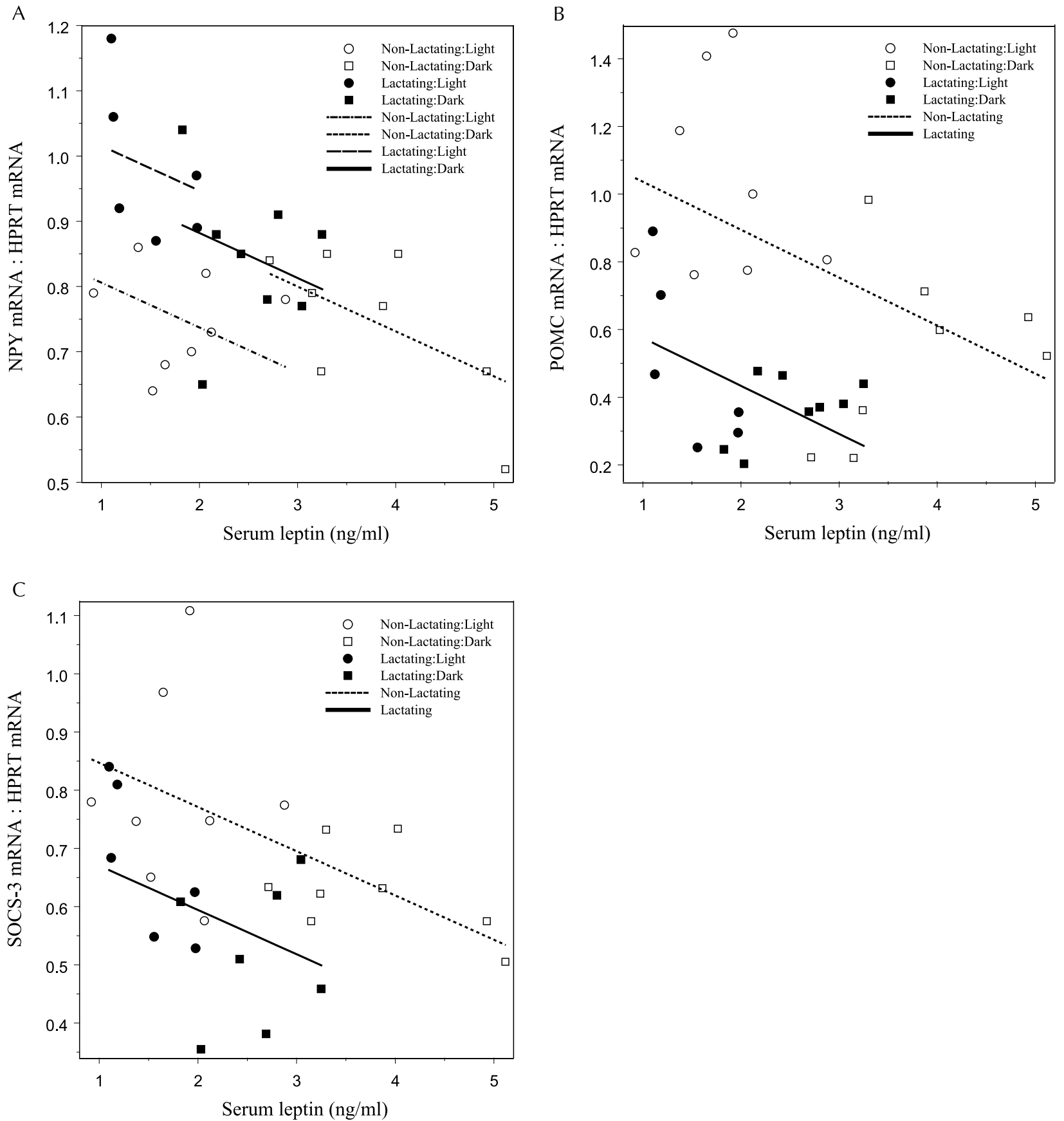

Figure 2 Hypothalamic expression of NPY (A), POMC (B) and SOCS-3 (C) as a function of serum leptin concentration. In each case the lines show the best-fitting regression model. For NPY, there was a significant state and light/dark phase interaction $(P=0 \cdot 02) ;$ when adjusted for this interaction, there was a significant correlation $(P=0.037)$ between NPY and leptin. For both POMC and SOCS-3 there was a significant effect of state $(P<0.001, P=0.002$ respectively), but no effect of light/dark phase on the regressions. When adjusted for state effect, there was a significant correlation between the POMC and leptin $(P=0 \cdot 007)$, and between SOCS-3 and leptin ( $P=0 \cdot 004)$.

changes in SOCS-3 reflect especially the status of the POMC neurones. Accordingly, multiple regression analysis of SOCS-3 as a function of POMC and NPY showed that $62 \%(P<0 \cdot 001)$ of variation in SOCS-3 expression could be explained by changes in POMC expression, with only an additional $5 \% \quad(P=0.039)$ of variation being explained by changes in NPY expression. The decrease in SOCS-3 expression during the dark again suggests a 


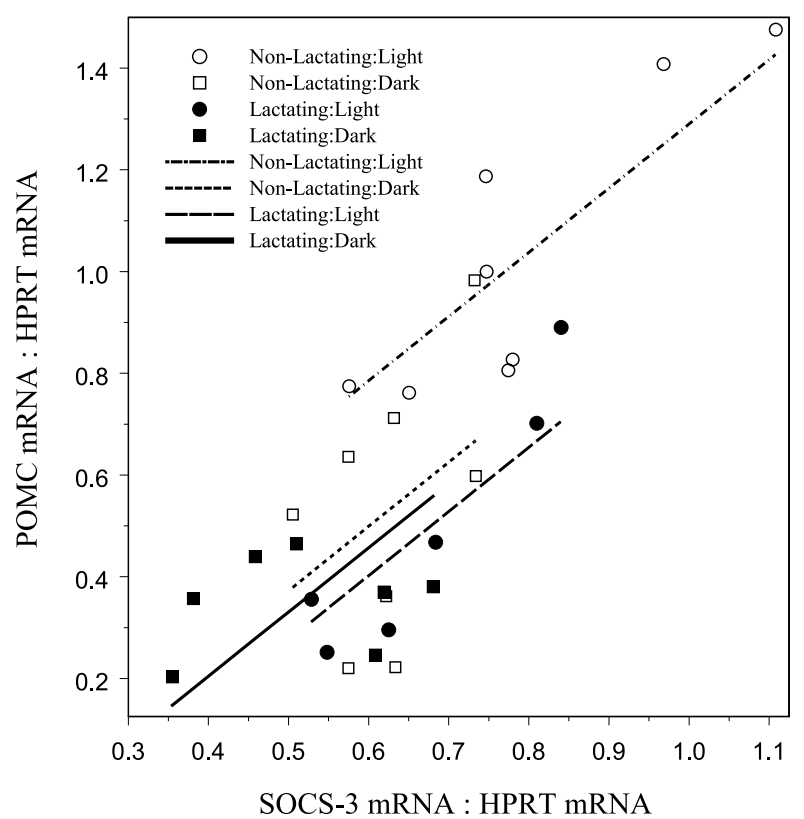

Figure 3 Hypothalamic expression of POMC as a function of SOCS-3. The four lines show the best-fitting regression model. There was a significant state and light/dark phase interaction $(P=0 \cdot 017)$; when adjusted for this interaction, there was a significant correlation $(P<0 \cdot 001)$ between the two variables.

constraint on leptin signalling through POMC neurones. Furthermore, the apparent failure of leptin to increase POMC expression at night is not due to increased expression of SOCS-3.

Effects of lactation on hypothalamic gene expression: relationship to leptin and food intake

Here, lactating rats showed increased hypothalamic NPY expression and decreased POMC during the day as compared with non-lactating rats. This agrees with previous findings (Ciofi et al. 1991, Pelletier \& Tong 1992, Smith 1993, Malabu et al. 1994, Pape \& Tramu 1996, Wilding et al. 1997, Li et al. 1998, Chen et al. 1999, Smith \& Grove 2002, Garcia et al. 2003) and is consistent with roles for both peptides in the hyperphagia. We did not find increased AgRP expression (measured in the whole hypothalamus) in the light phase, perhaps because the previously reported increase in AgRP during the daytime in lactating rats was confined only to some regions of the arcuate nucleus (Chen et al. 1999). However, AgRP expression was increased in the dark in our lactating rats. The fact that POMC expression did not decrease at night in lactating rats may be due to the level already being reduced in the daytime. Thus lactation alters both the expression of these three neuropeptide genes and also changes the diurnal pattern of expression of AgRP and POMC.

The mechanisms regulating hypothalamic neuropeptide gene expression during lactation have not been resolved, but both metabolic signals, such as leptin, and other factors, such as the suckling stimulus, are thought to be involved (Smith \& Grove 2002, Vernon et al. 2002). The increased NPY expression could be at least partly due to the hypoleptinaemia. However, when changes during the dark as well as the light are taken into consideration, changes in AgRP and POMC expression cannot be directly related to changes in leptin, implying that other factors are probably more important in regulating expression of these two genes.

The effect of lactation on hypothalamic SOCS-3 expression has not been described previously. As SOCS-3 is an inhibitor of leptin signalling (Björbaek et al. 1999), an increase in expression could result in diminished leptin signalling and so facilitate hyperphagia. However, SOCS-3 expression fell during lactation, consistent with the hypoleptinaemia, but potentially enhancing the ability of neurones to transmit leptin signalling, and so is unlikely to contribute to the hyperphagia.

While we measured total food intake per day $(14.3 \pm 1.7$ and $58.2 \pm 3.8 \mathrm{~g} / \mathrm{rat}$ for non-lactating and lactating rats respectively), we did not measure the proportion consumed during the light and dark periods in the present study. However, our own and other studies have shown that non-lactating and lactating rats consume respectively about 85 and $65 \%$ of their food at night (Strubbe \& Gorissen 1980, Munday \& Williamson 1983, Pickavance et al. 1996). From this, we estimate that our non-lactating rats would have eaten about 2 and $12 \mathrm{~g} / 12 \mathrm{~h}$ during the light and dark periods respectively, and the lactating rats about 20 and $38 \mathrm{~g} / 12 \mathrm{~h}$ during these periods. The expression of NPY, AgRP or POMC did not reflect this pattern of changes (Fig $1 \mathrm{~A}-\mathrm{C}$ ). By contrast, changes in the AgRP:POMC ratio (Fig. 1E) showed a close parallel with this pattern of food intake. Levels of mRNA do not necessarily reflect the amount of these neuropeptides, but the strength of the relationship strongly suggests that the balance of agonist versus antagonist signalling (rather than changes in either alone) through the MC4 receptor could have a major role in controlling both the diurnal feeding rhythm and also hyperphagia in lactation. In addition, increased expression of NPY may contribute to the hyperphagia of lactation, but changes in NPY expression would not appear to contribute to night-time eating.

\section{Acknowledgements}

We thank Sandra Paton and Sandy McBlane for care of the animals.

\section{Funding}

This study was funded by the Scottish Executive Environmental and Rural Affairs Department. There is no conflict of interest that would prejudice the impartiality of the research. 


\section{References}

Ahima RS 2000 Leptin and the neuroendocrinology of fasting. Frontiers in Hormone Research 26 42-56.

Ahima RS \& Flier JS 2000 Leptin. Annual Review of Physiology 62 413-437.

Ahima RS, Prabakaran D \& Flier JS 1998 Postnatal leptin surge and regulation of circadian rhythm of leptin by feeding. Journal of Clinical Investigation 101 1020-1027.

Ahima RS, Kelly J, Elmquist JK \& Flier JS 1999 Distinct physiological and neuronal responses to decreased leptin and mild hyperleptinemia. Endocrinology 140 4923-4931.

Ahima RS, Saper CB, Flier JS \& Elmquist JK 2000 Leptin regulation of neuroendocrine systems. Frontiers in Neuroendocrinology 21 263-307.

Ahren B 2000 Diurnal variation in circulating leptin is dependent on gender, food intake and circulating insulin in mice. Acta Physiologica Scandinavica 169 325-331.

Auernhammer CJ \& Melmed S 2001 The central role of SOC-3 in integrating the neuro-immunoendocrine interface. Journal of Clinical Investigation 108 1735-1740.

Barber MC, Clegg RA, Travers MT \& Vernon RG 1997 Lipid metabolism in the lactating mammary gland. Biochimica et Biophysica Acta 1347 101-126.

Baskin DG, Seeley RJ, Kuijper JL, Lok S, Weigle DS, Erickson JC, Palmiter RD \& Schwartz MW 1998 Increased expression of mRNA for the long form of the leptin receptor in the hypothalamus is associated with leptin hypersensitivity and fasting. Diabetes 47 538-543.

Baskin DG, Breininger JF \& Schwartz WM 2000 SOCS-3 expression in leptin-sensitive neurons of the hypothalamus of fed and fasted rats. Regulatory Peptides 92 9-15.

Björbaek C, El-Haschimi, Frantz JD \& Flier JS 1999 The role of SOCS-3 in leptin signaling and leptin resistance. Journal of Biological Chemistry 274 30059-30065.

Björbaek C, Buchholz RM, Davis SM, Bates SH, Pierroz DD, Gu H, Neel BG, Myers MG Jr \& Flier JS 2001 Divergent roles of SHP-2 in MAPK activation by leptin receptors. Journal of Biological Chemistry 276 4747-4755.

Bruckdorfer KR, Kang SS, Khan IH, Bourne AR \& Yudkin J 1974 Diurnal changes in the concentrations of plasma lipids, sugars, insulin and corticosterone in rats fed diets containing various carbohydrates. Hormone and Metabolic Research 6 99-106.

Cheni P, Li C, Haskell-Luevano C, Cone RD \& Smith MS 1999 Altered expression of agouti-related protein and its colocalization with neuropeptide $\mathrm{Y}$ in the arcuate nucleus of the hypothalamus during lactation. Endocrinology 140 2645-2650.

Ciofi P, Fallon JH, Croix D, Polak JM \& Tramu G 1991 Expression of neuropeptide Y precursor-immunoreactivity in the hypothalamic dopaminergic tubero-infundibular system during lactation in rodents. Endocrinology 128 823-834.

Denis RGP, Williams G \& Vernon RG 2003a Regulation of serum leptin and its role in the hyperphagia of lactation in the rat. Journal of Endocrinology 176 193-203.

Denis RGP, Bing C, Naderali EK, Vernon RG \& Williams G $2003 b$ Lactation modulates diurnal expression profiles of specific leptin receptor isoforms in the rat hypothalamus. Journal of Endocrinology 178 225-232.

Drouin J, Chamberland D, Charron J, Jeannotte L \& Nemer M 1985 Structure of the rat pro-opiomelanocortin gene (POMC). FEBS Letters 193 54-58.

Elias CF, Aschkenasi C, Lee C, Kelly J, Ahima RS, Bjorbaek C, Flier JS, Saper CB \& Elmquist JK 1999 Leptin differentially regulates NPY and POMC neurons projecting to the lateral hypothalamic area. Neuron 23 775-786.

Elmquist J 2001 Hypothalamic pathways underlying the endocrine, autonomic, and behavioral effects of leptin. Physiology and Behaviour $74703-708$
Elmquist JK, Elias CF \& Saper CB 1999 From lesions to leptin: Hypothalamic control of food intake and body weight. Neuron 22 221-232.

Friedman JM \& Halaas JL 1998 Leptin and the regulation of body weight in mammals. Nature 395 763-770.

Johnstone LE \& Higuchi T 2001 Food intake and leptin during pregnancy and lactation. Progress in Brain Research 133 215-227.

Kalsbeek A, Fliers E, Romijn JA, La Fleur SE, Wortel J, Bakker O, Endert E \& Buijs RM 2001 The suprachiasmatic nucleus generates the diurnal changes in plasma leptin levels. Endocrinology 142 2677-2685.

Kimura T, Maji T \& Ashida K 1970 Periodicity of food intake and lipogenesis in rats subjected to two different feeding plans. Journal of Nutrition 100 691-697.

Korner J, Wardlaw SL, Liu S-M, Conwell IM, Leibel R \& Chua SC 2000 Effects of leptin receptor mutation on AGRP gene expression in fed and fasted lean and obese (LA/N-fa) rats. Endocrinology 141 2465-2471

Li C, Peilin C \& Susan SM 1998 Neuropeptide Y neurons in the arcuate nucleus (ARH) and dorsomedial nucleus (DMH), areas activated during lactation, project to the paraventricular nucleus of the hypothalamus (PVH). Regulatory Peptides 75-76 93-100.

Lu X-Y, Sheih K-R, Kabbaj M, Barsh GS, Akil H \& Watson SJ 2002 Diurnal rhythm of agouti-related protein and its relation to corticosterone and food intake. Endocrinology 143 3905-3915.

Malabu UH, Kilpatrick A, Ware M, Vernon RG \& Williams G 1994 Increased neuropeptide $\mathrm{Y}$ concentrations in specific hypothalamic regions of lactating rats: possible relationship to hyperphagia and adaptive changes in energy balance. Peptides 15 83-87.

Mastronardi CA, Walczewska A, Yu WH, Karanth S, Parlow AF \& McCann SM 2000 The possible role of prolactin in the circadian rhythm of leptin secretion in male rats. Proceedings of the Society for Experimental Biology and Medicine 224 152-158.

Mercer JG, Moar KM, Rayner DV, Trayhurn P \& Hoggard N 1997 Regulation of leptin receptor and NPY gene expression in hypothalamus of leptin-treated obese (ob/ob) and cold-exposed lean mice. FEBS Letters 402 185-188.

Munday MR \& Williamson DH 1983 Diurnal variations in food intake and in lipogenesis in mammary gland and liver of lactating rats. Biochemical Journal 214 183-187.

Nishiyama MS, Makino S, Suermaru S, Nanamiya WW, Asaba T, Kaneda T, Mimoto T, Nishioka T, Takao T \& Hashimoto K 2000 Glucocorticoid effects on the diurnal rhythm of circulating leptin levels. Hormone Research 54 69-73.

Pape J-R \& Tramu G 1996 Suckling-induced changes in neuropeptide $\mathrm{Y}$ and proopiomelanocortin gene expression in the arcuate nucleus of the rat: evaluation of a putative intervention of prolactin. Neuroendocrinology 63 540-549.

Pelletier G \& Tong Y 1992 Lactation but not prolactin increases the levels of pre-proNPY mRNA in the rat arcuate nucleus. Molecular and Cellular Neurosciences 3 286-290.

Pickavance L, Dryden S, Hopkins D, Bing C, Frankish H, Wang Q, Vernon RG \& Williams G 1996 Relationships between hypothalamic neuropeptide $\mathrm{Y}$ and food intake in the lactating rat. Peptides 17 577-582.

Pickavance L, Tadayyon M, Williams G \& Vernon RG 1998 Lactation suppresses diurnal rhythm of serum leptin. Biochemical and Biophysical Research Communications 248 196-199.

Pritchard LE, Turnbull AV \& White A 2002 Pro-opiomelanocortin processing in the hypothalamus: impact on melanocortin signalling and obesity. Journal of Endocrinology 172 411-421.

Pu S, Dube MG, Kalra PS \& Kalra SP 2000 Regulation of leptin secretion: effects of aging on daily patterns of serum leptin and food consumption. Regulatory Peptides 92 107-111.

Rybkin II, Zhou Y, Volaufova J, Smagin GN, Ryan DH \& Harris RBS 1997 Effect of restraint stress on food intake and body weight is determined by time of day. American Journal of Physiology $\mathbf{2 7 3}$ R1612-R1622. 
Schwartz MW, Woods SC, Porte D Jr, Seeley RJ \& Baskin DG 2000 Central nervous system control of food intake. Nature 404 661-671.

Siegling A, Lehmann M, Platzer C, Emmrich F \& Volk HD 1994 A novel multispecific competitor fragment for quantitative PCR analysis of cytokine gene expression in rats. Journal of Immunological Methods 177 23-28.

Smith MS 1993 Lactation alters neuropeptide-Y and pro-opiomelano cortin gene expression in the arcuate nucleus of the rat. $\mathbf{1 3 3}$ $1258-1265$.

Smith MS \& Grove KL 2002 Integration of the regulation of reproductive function and energy balance: lactation as a model. Frontiers in Neuroendocrinology 23 225-256.

Steiner RA, Kabigting E, Lent K \& Clifton DK 1994 Diurnal rhythm in proopiomelanocortin mRNA in the arcuate nucleus of the male rat. Journal of Neuroendocrinology 6 603-608.

Strubbe JH \& Gorissen J 1980 Meal patterning in the lactating rat. Physiology and Behaviour 25 775-777.

Takahashi N, Patel HR, Qi Y, Dushay J \& Ahima RS 2002 Divergent effects of leptin in mice susceptible or resistant to obesity. Hormone and Metabolic Research 34 691-697.

Uotani S, Björbaek C, Tornoe J \& Flier JS 1999 Functional properties of leptin receptor isoforms: internalization and degradation of leptin and ligand-induced receptor downregulation. Diabetes 48 279-286.

Vernon RG, Denis RGP, Sorensen A \& Williams G 2002 Leptin and the adaptations to lactation in rodents and ruminants. Hormone and Metabolic Research 34 678-685.

Wade GN \& Schneider JE 1992 Metabolic fuels and reproduction in female mammals. Neuroscience and Behavioural Reviews 16 235-275.
Wilding JPH, Ajala MO, Lambert PD \& Bloom SR 1997 Additive effects of lactation and food restriction to increase hypothalamic neuropeptide Y mRNA in rats. Journal of Endocrinology 152 365-369.

Williams G, Steel JH, Cardoso H, Ghatei MA, Lee YC, Gill JS, Burrin JM, Polak JM \& Bloom SR 1988 Increased hypothalamic neuropeptide Y concentrations in diabetic rat. Diabetes 37 763-772.

Williams G, Chen B, Cai XJ, Harrold A, King P \& Liu X 2001 The hypothalamus and the control of energy homeostasis. Different circuits, different purposes. Physiology and Behavior 74 683-701.

Wise PM, Scarbrough K, Weiland NG \& Larson GH 1990 Diurnal pattern of proopiomelanocortin gene expression in the arcuate nucleus of proestrous, ovariectomized, and steroid-treated rats: a possible role in cyclic luteinizing hormone secretion. Molecular Endocrinology 4 886-892.

Xu B, Kalra PS, Farmerie WG \& Kalra SP 1999 Daily changes in hypothalamus gene expression of neuropeptide Y, galanin, proopiomelanocortin, and adipocyte leptin gene expression and secretion: effects of food restriction. Endocrinology 140 2868-2875.

Ziotopoulou M, Mantzoros CS, Hileman SM \& Flier JS 2000 Differential expression of hypothalamic neuropeptides in the early phase of diet-induced obesity in mice. American Journal of Physiology 279 E838-E845.

Received 3 June 2004

Accepted 17 June 2004

Made available online as an

Accepted Preprint 29 June 2004 